\title{
Effect of Consecutive Days of Match Play on Athletes' Physiology in Futsal
}

\author{
Agung Dwi Juniarsyah*, Tommy Apriantono, I Ketut Adnyana \\ Sports Science Research Group, School of Pharmacy \\ Institut Teknologi Bandung \\ Bandung, Indonesia \\ *agung@fa.itb.ac.id
}

\begin{abstract}
Nowadays Futsal is in great demand by various circles. Many people play this sport for leisure or for achievement. Aim of the study to compare the characteristics of physiology, heart rate, blood lactate levels, the number of steps, and energy expenditure for amateur futsal players in two consecutive matches. Total of eight amateur futsal players $(23.75 \pm 0.71$ years, $67.57 \pm 3.16 \mathrm{~kg}, 170 \pm 4.30 \mathrm{~cm}, 19.80 \pm 5.18 \%$ fat mass). The players compete in two consecutive matches. The research method used in this study is the experimental method. The results were obtained an average VO2 max $43.90 \pm 5.48 \mathrm{ml}$ $/ \mathrm{kg} / \mathrm{min}$. Mean heart rate of amateur team in first day $170 \pm 10$ and second day $174 \pm 10 \mathrm{bpm}(\mathrm{p}<0.05)$, the blood lactate level after the game in first day $6,35 \pm 2,67$ and second day $10.10 \pm 1.90$ $\mathrm{mmol} / \mathrm{L}(\mathrm{p}<0.05)$, the number of steps in first day $3285 \pm 877$ and second day $2864 \pm 494,64$ times $(p<0.05)$, energy expenditure in first day $551 \pm 96,27$ and second day $578 \pm 81.89$ kcal $(p<0.05)$. Physical fitness of amateur team are in good category. The activity of the futsal match for the amateur team are heavy activity. Distance covered the amateur team in second day is more less than first day, but the energy expenditure of amateur team in second day were larger than in the first day. The effect of two consecutive matches for amateur players is higher fatigue.
\end{abstract}

Keywords: amateur team, blood lactate level, energy expenditure, futsal, heart rate, the number of steps

\section{INTRODUCTION}

Futsal comes from Spanish language, is a combination of two words, "futbol and sala". Futbol which means football, and sala which means room. Futsal is football that is played indoors [1]. Futsal is in great demand by various circles in this age. Many people play this sport for performance and recreation.

Futsal is an intermittent sport that makes high demands in physical, technical, and tactics on the players [2]. When the match is held $2 \times 20$ minutes, the time stops when the ball is out of the field, the players injury, clearing the field, doing timeout, and so on. Each team can request a timeout (1 minute) in each round and a break of 15 minutes after the first half is over. The average duration of each match reaches $72.8 \pm 5.7$ minutes, with an average playing time of each player $34.2 \pm$ 18.1 minutes [3]. The unlimited number of substitutions makes the intensity and rhythm of the game very high and does not decrease during the match [4]. Futsal is a sport with very high intensity, so it requires good physical abilities, in addition to techniques and tactics for the players [2].
The futsal player spends more than $50 \%$ of his playing time on $80-90 \%$ intensity maximum heart rate, and blood lactate levels after the game reach an average of $5.3 \mathrm{mmol} / \mathrm{L} \mathrm{[5].} \mathrm{The}$ average maximal heart rate was reached in the first 10 minutes, and blood lactate levels after the match averaged $4.98 \mathrm{mmol} / \mathrm{L}$ [6]. The intensity produced by futsal matches is an average of $86 \%$ of the maximum heart rate, with energy expenditure generated at $18 \mathrm{kcal} /$ minute [3].

Indonesia has a National futsal competition, the Indonesian Futsal League which is now renamed the Pro Futsal League (PFL). PFL was established in 2006, until now it has held the league 10 times. The PFL uses a full competition system which consists of several series, making the competition take a long time and requires players to be able to maintain their physical condition during the competition. This competition consists of two regions, namely west and east which each region contains 8 teams of participants. The match schedule is held every 2 weeks in each region, with a 1 week format, two matches are held on weekends (Saturday and Sunday) for each team. The time to recover short physical conditions, less than 24 hours to the next game may affect the intensity and performance produced by the players. Based on professional league match schedules, amateur players are required to be able to adjust their physical abilities if they want to play on a professional level. Several studies have been carried out on physical conditions during futsal matches, but the authors have not yet found research on the physiological characteristics of amateur futsal players during consecutive matches, in this case two matches were held in two days. The purpose of this study is to determine the effect of two consecutive matches on the performance produced by futsal players.

\section{METHOD}

The research method used in this study is the experimental method. The research design used is the basic causal comparative design [7]. The study population was all players from one of the amateur teams in Bandung. The research sample was based on purposive sampling. All samples were in good health and were not injured, after that they were willing to fill in the informed consent provided. The criteria include: number of samples consisting of 8 amateur futsal players with ages between 19-27 years; playing for hobbies; and practice twice a week. 
The research instrument used in this study was bleep test to measure VO2 max, heart rate monitor for heart rate and energy expenditure, accoutred portable analyser for blood lactate levels, step pedometer for number of steps, and bioelectrical impedance analysis for body mass index, body weight and fat percentage.

\section{RESULTS AND DISCUSSION}

The characteristic physiology data amateur futsal players are showed in table 1 . In this study obtained the physiological characteristics for amateur players on the average age of 23.75 \pm 0.71 years, weight $67.57 \pm 3.16 \mathrm{~kg}$, height $170 \pm 4.30 \mathrm{~cm}$, body mass index $23.22 \pm 3,09 \%$, and fat percentage $19.80 \pm$ $5.18 \%$. Fat percentage of amateur players with a range of 15$22 \%$ is in the medium category. The average VO2 max of amateur players is $43.90 \pm 5.48 \mathrm{ml} / \mathrm{kg} / \mathrm{min}$ in good category. This VO2 max value shows the fitness status of amateur players in good category. Futsal players must at least have a minimum VO2 max of $50-55 \mathrm{ml} / \mathrm{kg} / \min$ to compete at the professional level [5].

TABLE I. CHARACTERISTIC PHySIOLOGY OF AMATEUR Futsal PLAYERS

\begin{tabular}{|l|l|l|}
\hline \multicolumn{1}{|c|}{ No } & \multicolumn{1}{|c|}{ Variable } & \multicolumn{1}{c|}{ Average } \\
\hline 1 & Age (years) & $23,75 \pm 0,71$ \\
\hline 2 & Weight $(\mathrm{kg})$ & $67,57 \pm 3,16$ \\
\hline 3 & Height $(\mathrm{cm})$ & $170 \pm 4,30$ \\
\hline 4 & BMI & $23,22 \pm 3,09$ \\
\hline 5 & Fat percentage $(\%)$ & $19,80 \pm 5,18$ \\
\hline 6 & VO2 max $(\mathrm{ml} / \mathrm{kg} / \mathrm{min})$ & $43,90 \pm 5,48$ \\
\hline
\end{tabular}

Figure 1 is amateur player's heart rate on the first day is 170 $\pm 11 \mathrm{bpm}$, equivalent to $87 \%$ of the maximum heart rate, while in the second match of $174 \pm 10 \mathrm{bpm}$, it is equivalent to $89 \%$ of the maximum heart rate. There is significant difference between first and second day $\mathrm{p}<0.05$. This research is in accordance with what Barbero revealed, if players perform sports activities more than $80 \%$ of their maximum heart rate, these activities are categorized in very heavy categories [2]. From the data produced in this study, it is seen that futsal matches are indeed activities that are categorized as very heavy, for amateur players in the second match are heavier than the first day.

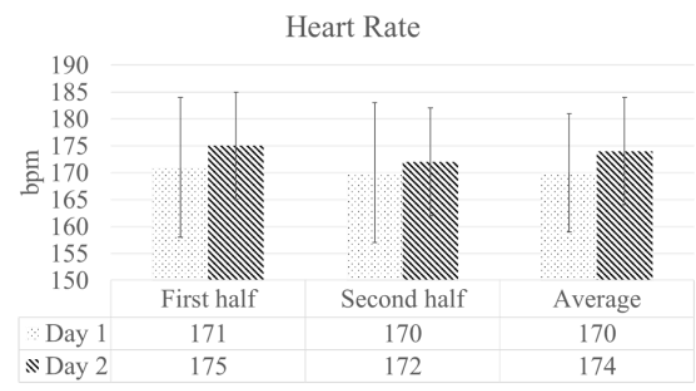

Fig. 1. Average heart rate amateur futsal palyers.
Recommendations from ACSM, intensity is divided into light ( $<65 \%$ HR max), moderate (65-85\% HR max), and very hard (> 85\% HR max) [8]. In the first match, the intensity of the light produced by amateur players was $2.78 \pm 2.53 \%$. Moderate intensity of $29.46 \pm 22.83 \%$, then very hard intensity of $67.76 \pm 24.79 \%$. In the second match very hard intensity expenditure $(>85 \% \mathrm{HR} \max )$ amateur players increased to $75.05 \pm 22.46 \%$, on the contrary for moderate intensity decreased to $22.36 \pm 20.32 \%$ even though there was no significant difference ( $p>0.05$ ) Based on the data obtained, confirms that more than $50 \%$ of the time to play futsal is spent at an intensity of $80-90 \%$ of maximum heart rate [5]. If the intensity is constantly high, it has the potential to make players make mistakes and fatigue that have a negative impact on the player's performance and also the team [9]. In accordance with the research that has been done, futsal is a multiple-sprint sport where high intensity exercise is a proportion that is greater than the time of the match [2].

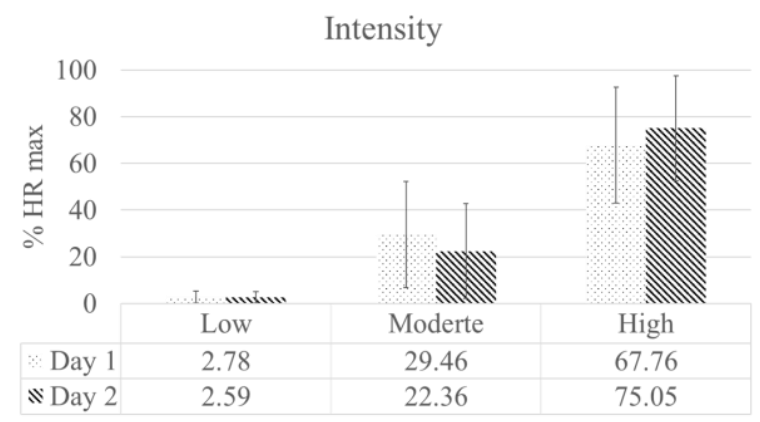

Fig. 2. Average intensity amateur futsal players.

In the first and second day matches, before first halves, the average value of blood lactate levels was $1.73 \pm 0.37$ and 1.76 $\pm 0.41 \mathrm{mmol} / \mathrm{L}$, not significant different $(\mathrm{p}>0.05)$. Blood lactate levels after second halves on the first and second days were $6.35 \pm 0.37$ and $10.10 \pm 1.90 \mathrm{mmol} / \mathrm{L}$, significant different ( $\mathrm{p}<0.05)$. Blood lactate levels produced by professional players in previous studies ranged from 4.98-5.3 mmol / L [5,6] In this study, amateur players produce blood lactate levels above the average value of professional players, especially the resulting blood lactate levels on the second day are higher than the first day, showing futsal activity on the second day was more tired experienced by amateur players.

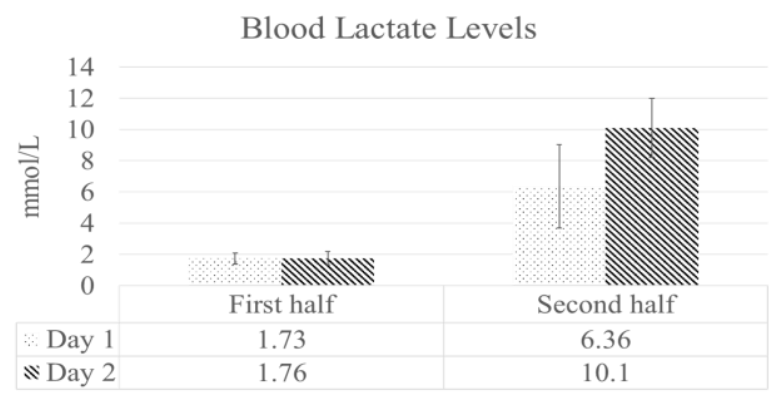

Fig. 3. Average blood lactate levels amateur futsal players.

Energy expenditure for amateur players in the first day match $551 \pm 96.27 \mathrm{kcal}$. In the second day match, amateur players' energy expenditure was $578 \pm 81.89 \mathrm{kcal}$. There was 
Indonesia have quite far enough when compared to the other countries.

\section{CONCLUSIONS}

For amateur players, matches that are held in two consecutive matches cause higher fatigue the next day. If players want to play in a professional level, they must be able to increase their physical abilities. In addition, the players must improve their technique and tactical individual for playing effectively.

\section{REFERENCES} match, the result of the number step amateur players was 2864 \pm 494.64 times, statistically significant different $p<0.05$. There is showing that was a decrease in amateur players distance covered during the second day match, while the heart rate was higher. Shows amateur players cannot maintain their performance during the second day match

\section{DISCUSSION}

In this study Futsal activity have a high intensity and if higher, it produce the high lactate too, and if it have high fatigue, it will also have an impact on higher energy expenditure. A team will be successful if produces less high intensity, because if the high intensity continuously has the potential the players makes mistakes and exhaustion that have negative effects on the players performance and the team [9].

Activity futsal matches for amateur players is in a very heavy category, it is not enough just to have VO2 max in good category, players must be able to increase their physical abilities. If players want to play in a professional level, they must be able to adjust the demands of the game and the competition. Futsal is an intermittent high intensity game that heavily taxes the aerobic and anaerobic pathways. Futsal players must at least have a minimum VO2 $\max$ of $50-55 \mathrm{ml} / \mathrm{kg} / \mathrm{min}$ to compete at the professional level [5]. The previous study showed for professional futsal player in Spanish League $64.6 \mathrm{ml} / \mathrm{kg} / \mathrm{min}$ [2], in Brazil league 71.5 $\mathrm{ml} / \mathrm{kg} / \mathrm{min}$ [3], and semi-professional in Italian League 55.2 $\mathrm{ml} / \mathrm{kg} / \mathrm{min}$. The result VO2 $\mathrm{mx}$ of amateur futsal player in
[1] FIFA Futsal LOTG 2010/2011, [cited 201623 Juli], Available from: http://www.fifa.com/mm/document/affederation/generic/51/44/50/spielr egelnfutsal_2010_11_e.pdf, 2016.

[2] J.C. Barbero-Alvarez, V.M. Soto, V. Barbero-Alvarez and J. GrandaVera, "Match analysis and heart rate of Futsal players during competition," J Sports Sci 26, pp. 63-73, 2008.

[3] M. Vinicius, "Intensity of Official Futsal Maches," Journal of Strength and Conditioning Research 25, 9, 2011.

[4] J. Alvarez, L. Gimenez, P. Corona, and P. Manonelles, "Necesidades cardiovasculares y metabolicas del futbol-sala: analisis de la competicion," Apunts, vol. 67, pp. 45-53, 2002.

[5] C. Castagna, S. D’Ottavio, J. Vera, J. Alvarez, "Match demands of professional futsal: a case study," J Sci. Med. Sport, vol. 12, pp. 490494, 2008.

[6] Erkal Arslanoğu1, Sümer Alvurdu, Temel Çakıroğlu, Ömer Şenel, "Heart rate and lactate changes in elite futsal players during a game," International Journal of Sports Science 2014, vol. 4(6A), pp. 71-74, 2014.

[7] Frankael, "How to design and evaluate research in education 8th edition," The McGrow-Hill Companies, 2012.

[8] S. Woolford, and M. Angove, "A comparison of training techniques and game intensities for national level netball players," Sports Coach, 14,18 -21.] A.J. Murphy, R. G. Lockie and A.J. Coutts, "Kinematic Determinants of Early Acceleration in Field Sport Athletes," in Journal of Sports Science and Medicine, vol. 2, pp. 144-150, 2003, 1991.

[9] E. Rampinini, F. M. Impellizzeri, C. Castagna, A. J. Coutts, U. Wisloff, "Technical performance during soccer matches of the italian serie a league: effect of fatigue and competitive level" J Sci Med Sport, vol. 12, pp. 227-233, 2009.

[10] M.A. Van Baak, "Physical activity and energy balance," Journal of Public Health Nutrition, vol 2(3a), 335-339, 1999 